DOI: $10.17516 / 1997-1370-0728$

УДК $37.013=111$

\title{
Educative Event as Professional Skills Transfer Method: The Young Reporters' Programme at the XXIX Winter Universiade 2019
}

\author{
Kseniya A. Rutskaya*, Elena M. Nazarenko \\ and Oksana A. Kol'k \\ Siberian Federal University \\ Krasnoyarsk, Russian Federation
}

Received 09.12.2019, received in revised form 12.01.2021, accepted 06.03.2021

\begin{abstract}
The Young Reporters' Programme (sports journalism and media school) presented at the XXIX World Winter Universiade 2019 in Krasnoyarsk was «a project within the project». The article describes key conditions and methods for organizing the transfer of professional skills and defines key structural elements in sports journalism and media school within a large-scale sporting event.

Special attention is given to solving two problems: creating high-quality media content by students during the Universiade; and identifying universal technological elements for designing a sports journalism and media school that would allow participants to master modern tools and apply them after completing the Young Reporters' Programme.

The approach of B.D. Elkonin and M.M. Mirkes to describing components of an educative event is the methodological basis of the study. The presented survey data are the result of implementing the Young Reporters' programme in Krasnoyarsk in 2019. It was the first time when the professional media training for covering a large-scale international sporting event has been developed, implemented and described. The findings of this study may be used for designing internships and student practical sessions at universities with the main educational process considered as a certain project.
\end{abstract}

Keywords: educative event, transfer of professional skills, intensive school, media education, media school, sports journalism, media content, Universiade.

Research area: pedagogy.

Citation: Rutskaya, K.A., Nazarenko, E.M., Kolk, O.A. (2021). Educative event as professional skills transfer method: the Young Reporters' Programme at the XXIX Winter Universiade 2019. J. Sib. Fed. Univ. Humanit. Soc. Sci., 14(3), 375-384. DOI: 10.17516/1997-1370-0728.

(C) Siberian Federal University. All rights reserved

* Corresponding author E-mail address: kbazhenova@sfu-kras.ru ORCID: 0000-0003-1989-553X (Rutskaya) 


\title{
Образовательное событие как инструмент трансфера профессиональных компетенций на примере проекта интенсивной медиашколы для молодых журналистов на Всемирной зимней универсиаде-2019
}

\author{
K.А.Руцкая, E.М. Назаренко, О.А. Кольк \\ Сибирский федеральньй университет \\ Российская Федерачия, Красноярск
}

\begin{abstract}
Аннотация. В статье представлены результаты апробации методов проектирования и реализации образовательных событий, направленных на трансфер профессиональных компетенций, на примере проекта интенсивной медиашколы «Молодой репортер» в области спортивной журналистики в рамках XXIX Всемирной зимней универсиады 2019 года в Красноярске. Программу для молодых журналистов на Универсиаде можно рассматривать как «проект в проекте». Выделенные авторами ключевые условия организации трансфера профессиональных компетенций могут быть использованы при проектировании стажировок и практик студентов в университетах, когда основной учебный процесс может быть рассмотрен как отдельный проект.

Основное внимание авторов программы было уделено решению двух задач: созданию студентами качественного медиаконтента во время проведения Универсиады, а также выделению универсальных технологических элементов для проектирования медиашколы, которые позволили бы участникам освоить современные средства журналистики и применять их вне ситуации интенсива.

Методологическая основа проекта - составил подход Б. Д. Эльконина, М. М. Миркес к описанию составляющих образовательного события. Сделано предположение о ключевых структурных элементах организации интенсивных медиашкол для молодых журналистов в процессе проведения масштабного спортивного события. Данные опроса получены на медиашколе «Молодой репортер». Подобный формат медиаобучения, имеющего профессиональный характер, при освещении международного спортивного события разработан, реализован и описан впервые.
\end{abstract}

Ключевые слова: образовательное событие, трансфер профессиональных компетенций, интенсивная школа, медиаобразование, медиашкола, спортивная журналистика, медиаконтент, Универсиада.

Научная специальность: 13.00.00 - педагогические науки.

\section{Introduction}

World Student Games have been held since 1923. At the Universiade in Kazan in 2013 a media school was launched for the first time. However, there are no open access studies or publications on the design concept and results of the media school in Kazan. In March 2019 the $29^{\text {th }}$ World Winter Universiade was held in Krasnoyarsk. The Young Reporters' programme sports journalism and media school was a part of the Universiade. Six participants from six foreign countries (Canada, South Africa, Federal Democratic Republic of Nepal, the USA, and Australia) and twelve Russian journalists from Moscow, Pskov, Barnaul, Arkhangelsk, Magnitogorsk, Omsk, Lytkarino, St. Petersburg came to Krasnoyarsk to cover the events on March, 2-12, 2019.

The project was developed in accordance with the direct order from FISU and had two goals. First, publishing high quality media content about the Universiade using modern 
media; the authors of the publications were supposed to be young reporters. Second, creating an educative event for seniour students enrolled in journalism, and solving professional tasks arising at the level of large-scale sport events. The authors of the article worked out an educational project - Young Reporters' program - which was not only rich in engagement, but also offered the participants the opportunity to master modern tools and standards in journalism while covering a largescale event. The work involved challenging professional debuts and implied the idea of using modern tools and standards in professional activity during the media school and on its completion.

The authors have chosen the form of an educative event as the project idea. The concept of «educative event» was first considered at the beginning of the $21^{\text {st }}$ century by Russian authors. It was used to record modern unique educational projects granting their participants with vivid emotional experiences and significant subjective outcomes (professional or creative). T.M. Kovaleva considers the context of the event as a necessary condition, namely anthropological context, for tutoring (Kovaleva, 2018). K. A. Bazhenova (2015) examines educative event as the basis for designing intensive schools. Philosophical understanding of the concept «educative event» was first described by B. D. Elkonin (2017). The requirements to the design of educational environment as an educative event for the participants were described in prior works (see Mirkes, Mukha, 2010).

The article describes the project idea, key elements and results of the sports journalism and media school. The description of the media school for sports journalists at a large-scale sporting event is being published for the first time.

\section{Theoretical framework}

The authors regard instructional design of a media school in the context of finding modern means of professional training for sports journalists, which is described in both Russian (Bespalova, Kuznetzova, 2018; Frolova et al., 2018) and international works (Weedon et al.,
2018; Miller, 2006; Muchtar, Hanitzsch, 2013; Nölleke, 2017).

In our case, the term «event» has at least two different meanings. First, when we talk about the Universiade as a large-scale sporting event, it is the news opportunity itself. Second, when we talk about the concept of an educative event as the basis of a media school.

The concept of «event» from the point of view of creating media content is considered in (Tzelepis et al., 2016), as well as the importance of training journalists in creating content that will be treated as an event. There is currently no united approach to creating an event model in the multimedia environment. The developers of the event point out the significance of interaction, the circumstances of space and time for the event, as well as the emotional involvement of both the author and the reader, so that the readers could discover a new image of themselves. This echoes with the philosophical approach of Elkonin and Mirkes (Elkonin, 2017; Mirkes, Mukha, 2017).

The educative event model is described by B.D. Elkonin (2017), M. M. Mirkes (Mirkes, Mukha, 2010). B. D. Elkonin identifies the following significant elements of an educative event and eventivity within philosophical context (Elkonin, 2017):

1. An event implies that a person understands modus operandi and his involvement in the activity. It is necessary to interrupt the natural flow of life; to work deliberately and intensively, to make an effort aimed at reaching, retaining and reconstructing the ideal structure (content and methods of activity).

2. An obligatory structural element of the event is the need of transition from one type of behaviour to another, constructing new behaviour when the existing pattern becomes insufficient. The present situation becomes a test field for implementing the idea (Elkonin, 2017).

3. B.D. Elkonin analyses the interrelation of three significant transitions, which become essential structural elements for the event. First, the transition of activity from everyday to intense one. Second, the transition in the physical body: a person begins to feel his own effort and well-being as inspiration or depression, 
such description is important for concentration on the effect of the event. Third, transition in experience; naming the obtained experience serves the factor for updating and reconstructing the possible supports of action.

4. The phenomenon of the event is associated with the cognition by the person of his/ her capabilities and the activity he/she is involved in. There are signs that show that something was an event for a person. First, a person moves from solving other people's problems to solving their own ones, there appears his/her own meaningful request (and this is different from simulating inclusion). This is the task of an event that was set up at the stage of the event planning. Second, after the experienced event, the person highlights other accents for his/her next trial. A person starts selecting those methods of action that he/she experienced.

5. The three aspects of accomplishing an action are connected with awareness. The first is the result; a person can define what has been learned. The second is the product. The third is the new field of action that emerged.

The theory suggested by B.D. Elkonin, and the structural elements for designing eventbased educational formats (Mirkes, Mukha, 2010; Elkonin, 2017) bring us to the following conclusions:

1. An educative event models a specific field of activity or culture (in its ideal form).

2 . The participants are involved in productoriented activity. The event is the environment for competence-based professional debuts. Projecting intensive training within the key activity is described in literature (Bazhenova, 2015).

3 . The schedule of the educative event and the available tasks are not strictly determined, leaving room for the subjective behaviour of the participants.

4. High intensity and open character of the event schedule, energetic and challenging character of the activity initiate subjective actions and further activity (the participants are aware of the transitions taking place, and of being «here and now»).

5. Energetic, in accordance with B. D. Elkonin (2017), and extreme character described by M. M. Mirkes (Mirkes, Mukha, 2010) is set and maintained due to the content, by the for- mat of the event, professionals involved, and the large scale of the event.

Russian authors emphasize the relevance of designing special educational forms for young journalists and students, the formats offering the opportunity to master modern professional technologies and, what is more important, be able to apply them in their professional activity outside the classroom (Frolova et al., 2018; Bespalova, Kuznetzova, 2018). Today, new effective approaches and methods of professional media education are in demand, with those employed in short-term media projects joining media schools and workshops for journalists (Miller, 2006; Muchtar, Hanitzsch, 2013). Sports reports acquire particular social significance in the modern world. Consequently, there is a need to train young journalists to produce high-quality sports content (Weedon et al., 2018). The importance of large-scale sports events for communication and reporting is emphasized (Nölleke, 2017). Methods of training sports journalists are presented in prior works (Alekseev, Il'chenko, 2013). Excellent methods of training journalists are widely used (Hultén, Edwardsson, 2018).

\section{Statement of problem}

At present we can state that there is no description of media schools held within largescale thematic events. Literature covers only sporadic effective methods of training journalists, and descriptions of trainings devoted to individual skills transfer.

It is known that an intensive short-term form for transferring skills and solving a project task is a sports journalism and media school, which is organized as an educative event. However, implementation of educative event is described for adolescents only (Mirkes, Mukha, 2010; Elkonin, 2017). In our case, we could not directly use the instructions given in the text as there were two obvious limitations:

- participants were students having professional interest in sports journalism;

- a school had to be a part of a largescale international event that took place in a metropolis, other than a local event.

The pedagogical task is developing and implementing a method for transferring skills 
from professionals - sports journalists to students within a large-scale thematic event. As we see it, planning and implementation of an educative event of a professional character involves professional skills transfer. Hereinafter, this term means the transfer of skills from experienced professionals to young professionals related to qualitative changes in independent professional activity.

\section{Methods}

The main sources for writing this article were publications devoted to intensive schools, focused on the productive use of professional debuts occurring within such projects. In the process of project planning the authors employed activity-based approach.

The data for analyzing the project's efficiency were obtained from the survey, interviews of the media school participants, and observation. The following information materials were published during the Young Reporter's program: 16 publications on the website of the Krasnoyarsk 2019 Universiade Directorate, 12 publications in the electronic newspaper, 157 publications in blogs, 87 photos for the daily electronic newspaper, social networks and the website of the Krasnoyarsk 2019 Universiade Directorate.

Access to the survey data and questionnaires may be obtained by submitting a request to the head of the media school.

\section{Discussion}

The work on developing the Young Reporters' program consisted of the following stages:

- projecting (selecting the project idea, coordinating the specifications with the FISU, working out the selection criteria, developing requirements for practical tasks, etc.);

- organizing (selecting participants, mentors and lecturers, organization of platforms, working out the program together with the mentors and lecturers);

- holding the event (implementing the program, carrying out surveys, etc.);

- analyzing (analysis of the results of the media school).

In our project the participants were students from different countries. In this regard at the projecting stage we took into account the following: designing the environment for «meeting» the old modus operandi with the new one, intention and the search for opportunities and resources to transform the old experience. The role of the mentor is to equip young specialists with indispensable skills, to help record the «meeting» and see the transitions (situations, physical body, experience). Reflection should be associated with observing whether a person appeals to this experience or not.

The specific features of designing eventbased educational formats described above is the core of the Young Reporters' program design for sports journalists at the $29^{\text {th }}$ World Winter Universiade. This section is devoted to realization of the project.

1. A specific field of activity or culture was modelled within an educative event.

The major activity was sports journalism. The curriculum of sports journalism and media school included modern ways of professional interaction, and high quality content being developed within the Universiade, with the guidance the participants got from industry experts. Inordinate attention was given to the following aspects of training:

- technology of news gathering and ethical issues (quality of news, freedom of speech and confidentiality (Pavlik, 2019);

- manner of presenting information to different target audiences (Stöckl, 2017; Lee, Lindsey, Kim, 2017).

The choice of topics presented an important task. History of sports journalism and its modern state of the art indicate that not only the method of providing information has changed from printed to digital, but the two other major factors have changed as well. First, the consumer himself, and consequently the method of providing information. Second, recognition of sports journalism as a commercially significant industry (Hutchins, Boyle, 2017; Boyle, 2017). Ureta and Fernandez (2017) describe methods of training journalists to work in social networks and convergent media. At the same time; a special role of bloggers who provide additional content for the mainstream media in sports journalism was recognized (McEnnis, 2017). 
A sports journalist prepares materials for publication in periodicals and on television. The task of the photo reporter is to take photographs of events to convey the intense emotions of a sporting event; it involves panoramic photos, 360 degree images, 180 degree images, etc. A blogger prepares materials for publishing in online media, social networks, and personal blogs. These are texts, photos, short videos with comments from experts, athletes and fans. A blogger has a minimum of time for completing a media product.

We identified three areas of training for the participants of the Universiade media school in Krasnoyarsk: a sports reporter, a sports journalist for online media (a blogger), and a sports photo reporter. The training programmes were developed taking into consideration specific features of each area. The participants stated the area of their interest (a sports reporter, a sports journalist for online media (blogger), a sports photo reporter) in their applications.

Daily lectures and master classes were organized by international and Russian experts. The lecturers were well-known international journalists in the field of sports. A well-known independent journalist, a chief editor of a sports website, a press photographer, a correspondent from an online resource, an executive director of a media group, a well-known sports photo reporter, a director of a football club and a network director were among the experts.

2. The participants were involved in product-oriented activity. The event unfolded as environment for competence-based professional debuts. They were aimed at an understanding the mechanism taking place in real life.

The Young Reporters' programme involved the participants in content production and publishing in the existing media. The participants received individual assignments from mentors. The tasks for reporters included a list of preliminary requirements: the topic, main plot lines, the details that were bound to be emphasized, the number of characters in the publication, the list of interviewees (their status or position) to be included in the final text, type/ genre of the publication, emotional component, organizational details of the work in the sports field. The tasks for photo reporters outlined the requirements for professional sports photography: the genre, the nature of the photo shot, the rules of behaviour to be followed by a sports photo reporter at the location, specific characteristics of a sports event and the athletes' behaviour. Then the reporters and photo reporters visited sports events and prepared a publication.

The final materials were assessed by the mentors and experts. The mentors were individual supervisors who accompanied the participants to sports events, offered individual tasks, and assessed the work before publishing in the media. The participants of the Young Reporters' media school were selected according to the preliminary defined criteria: age - from 21 to 25 years, seniour students majoring in journalism and public relations from different countries, young reporters working with a wide variety of topics who have publications in the media devoted to sports, and a certain number of followers in social networking groups. The participants had to speak English fluently and endure an in-person interview with experts. Such selection made it possible to create conditions for productive interaction of the participants, as well as the opportunity of professional communication at a high level.

3. The schedule of the educative event and the available tasks were not strictly determined, leaving room for the subjective behaviour of the participants.

The nature of the tasks implied creative character of interaction. The work of the editorial board of the Young Reporters' programme took place on a 24 hours/day basis. The school schedule enlisted visiting sports locations and doing the tasks in varied groups. Photo reporters worked together with journalists. The schedule allowed them to choose the succession of sports competitions, and the original approach to creating sports materials. Each of the participants of the media school was able to work in accordance with their own schedule when covering the events of the 2019 Winter Universiade.

The complexity of professional tasks a sports journalist may have experienced is related to the specific character of working at sport- 
ing events. All participants understood that it was necessary to prepare a journalistic message promptly, the message should have been clear to the audience, had to contain an expert opinion, and convey the intense emotions of the event. The same concerned the photo reporters' work as well.

4. High intensity and open character of the event schedule, energetic and challenging character of the activity initiates subjective actions and further activity (the participants' awareness of transformations taking place and their awareness of being here and now).

The participants assessed their idea and the final product quality. Supported by the mentor's opinion such analysis initiated subjective actions. The experts, while giving feedback, used the criteria worked out in advance at the stage of planning.

The open character of assessing achievements and results was a characteristic feature of the project. Twice a day, media school mentors held meetings where achievements and mistakes of each participant were discussed, and proposals were developed to solve the arising problems. All the participants of the media school were immersed in a united emotional environment, they realized the importance of learning, their mission in covering international student games.

Individual consultations with mentors allowed the participants to discover their strengths and deficiencies (gaps between the ideal image of themselves and the reality), set and reach goals, find or create resources to do the task. event.

5. Energetic and extreme character of the

Energetic, in accordance with B. D. Elkonin (Elkonin, 2017), and extreme character as described by M.M. Mirkes (Mirkes, Mukha, 2010) is set and maintained not only due to the content, but also due to the format of the event, due to the professionals involved, and the large scale of the event.

The energy of such an event as a media school is determined by its scale and focus of the professional character on sports journalism. The interaction and cooperation are organized by means of individual work of the participants of the media school with mentors - professionals in this area.

During the last days of the program the surveys among the participants of the program were carried out. All the participants of the Young Reporters' international media school took part in the survey. The criteria showing the success of the event are the emotional involvement of the participants in the work, the ability to find professional tools to perform the task, understanding of how the mastered method can be used outside the intensive media school.

The participants admitted that the training was effective. Their motivational forces included obtaining specific knowledge in sports journalism; developing their product when covering an international sporting event; and further professional growth. The organizing committee and mentors managed to create real life professional situations. More than $80 \%$ of respondents confessed that they had learned more while doing practical tasks than during lectures. The participants of the media school enumerated the following individual achievements while preparing publication materials:

- developing quick response skill;

- meeting the deadlines and the feeling of «being independent»;

- independent search for exclusive topics and developing «professional flexibility»;

- the opportunity «to prove myself that I can produce content of a good quality»;

- increased skills in video editing for social networks;

- satisfaction from the completed essays and a positive assessment from the mentor.

At the final meeting of the media school the students exchanged their experiences and shared their personal ideas of what was the most important for each of them. The participants said they:

- managed to master SMM, infographics, and sports photography;

- got acquainted with the editorial policy of various media;

- learned the rules of working in mixed zones, and at press conferences;

- mastered the new sports terminology; 
- were taught to write materials within a limited time period;

- learned how to create exclusive content;

- gained experience of interaction with athletes and volunteers.

We asked the participants a question: "What is your general impression from a media school?» The range of participants' answers included: «working non-stop», «plenty of information and amazing acquaintances», «mastering an insane amount of material within 10 days», «the professional details, the secrets skills», «I became a professional journalist, I believe in myself», "we had a dream team», «I realized that I was not mistaken in my choice of profession», «this event helped me to understand how important the role of a journalist is».

The answers cited above illustrate the involvement of the participants in the process, but they do not give us any chance to assess the pending results within a longer period of time. A month later, when emotions subsided, the participants of the media school were asked to write an essay about how they use the knowledge and experience gained within the media school. We received such a feedback from a participant from Arkhangelsk: «I have been blogging since I was 16 years old. However, I did manage to catch the emotions, not facts... I had difficulty in presenting complex events... I told the mentor about my difficulty. He gave me useful advice. We discussed each of my works together. And I got the result I liked materials about the athletes who did not win, about the guests of a large-scale sports festival, about the cultural programme in the city. These are different texts from the point of view of emotion. Now I continue writing for my blog. Probably, I will be able to use the advice I got from the mentor for solving other difficulties.») The participant from Pskov (a photo reporter) said as such: «The most important thing I learned at the media school is how to behave on the sports ground to get a great shot. I used to have problems with this; everything happens on the ground too dynamically... But working with a mentor I realized that one needs professional equipment; instead of shooting at eye level you can lie on the floor - this is another angle which provides you with the opportunity to tell a completely different story. I realized that one shouldn't be afraid to try new things. I had a talk with my director - we are buying a professional camera.»

A considerable element of the educative event is the emotional experience of the participants. The questionnaires show the emotional involvement of media school students. They mention «a sense of belonging to something great,» «I have never experienced anything like that and feel a real journalist, «I am proud to have participated in this event». All the participants admitted «the grandeur of the event».

These feedback responses indicate that the intensive school project within the Universiade not only became a rich emotional event, but also had a palpable impact on professional growth of the participants.

\section{Conclusion}

The obtained project outcomes prove that the international media school organized within a large-scale event helped to solve the following tasks:

- train young journalists to cover a large-scale sporting event in accordance with modern approaches;

- create an educative event for the participants of the Young Reporters' programme which helped them use their skills;

- organize the students' independent work to produce the materials covering the $29^{\text {th }}$ Winter Universiade in Russian and international media;

- establish that the process of transferring skills within the event-based approach supports the opportunity to effectively achieve professional results; and create another educational environment that goes beyond the usual lifestyle of the project participants.

The analysis of the project outcomes makes it possible to single out key structural elements for developing an educative event such as an intensive media school to cover a largescale sporting events:

- the methodological approach of M. M. Mirkes and B. D. Elkonin is the valid basis for designing organizational elements; 
- the content, forms and methods used within the media school serve to provide students with opportunity to make professional debut in sports journalism;

- selecting the participants and mentors of the media school creates conditions for effective professional communication and reflection of the participants' professional debut;

- reflection is necessary for the participants to realize that the event is part of life outside (three aspects of eventivity in accordance with B.D. Elkonin see above);

- the scale of the sporting event is used as a challenge that initiates the subjective action of the participants.

The results of this project are useful and may be applied in projects of federal and regional levels, when a large-scale project launch other projects - satellites; in organizing other large-scale events, arranging for lectures, special courses and media school workshops.

All project participants admit that participation in such a short-term activity-based and event-based media education project creates conditions for professional skills development, supports their responsibility, teamwork skills, and ability to carry out independent creative research and interaction. The analysis of the sports journalism and media school results demonstrates school's validity for additional training of novice sports journalists.

We assume that the set of organizational and pedagogical conditions worked out within implementing the Young Reporters' programme may be used to develop similar intensive schools and simulation practical sessions for students - future journalists. The obtained results support the existing in pedagogical science knowledge of postgraduate professional development and professional skills transfer for journalists; and can serve as a basis for further theoretical and practice-oriented research in the field of education management and additional professional education for sports journalists.

\section{References}

Alekseev, K.A., Il'chenko, S.N. (2013). Sportivnaia zhurnalistika: uchebnik dlya magistrov [Sports journalism: Tutorial for Master's program students]. Moscow, Urait Publishing house, 428 p, available at: www.biblio-online.ru/bcode/374857

Bazhenova, K.A. (2015). Proektirovanie intensivnoi shkoly po osvoeniiu issledovaniia kak vida deiatelnosti [Designing an intensive school for mastering research as activity]. In Sbornik trudov II Mezhdunarodnoi konferentsii «Deiatelnostnaia pedagogika i pedagogicheskoie obrazovanie» [Proceedings of the II International Conference «Activity-based pedagogy and pedagogical education»], 3-12.

Bespalova, A.G., Kuznetzova, A.V. (2018). Interactive Practice-Oriented Techniques in Professional Media Education. In Media Education (Mediaobrazovanie), 58(4): 11-21.

Boyle, R. (2017). Sports Journalism. In Digital Journalism, 5(5): 493-495. DOI: $10.1080 / 21670811.2017 .1281603$

Elkonin, B.D. (2017). Obrazovanie za predelami obydennogo: sobytie deistviia. sobytie ucheniia - sobytie sebia [Education outside the ordinary: action event, educative event - event of one's self]. In Nekommercheskoe partnerstvo «Avtorskiy klub» [Non-profit partnership Author's Club], $256 \mathrm{p}$.

Frolova, E., Ryabova, T., Rogach, O. (2018). Interactive Technologies of Forming the Students' Media Competence: Opportunities and Limitations of Their Use in Contemporary Educational Practice. In $\mathrm{Me}$ diaobrazovanie [Media Education], 58 (4): 22-28.

Hultén, G., Edwardsson, M. (2018). Storylab lessons: A collaborative project between courses in journalism and media technology. In Nordicom Review, 39: 3-17. DOI: 10.1515/nor-2017-0417

Hutchins, B., Boyle, R. (2017). A Community of Practice Sport journalism, mobile media and institutional change. In Digital Journalism, 5(5): 496-512. DOI: 10.1080/21670811.2016.1234147

Kovaleva, T.M. (2018). T'utorskoie soprovozhdenie studentov pedagogicheskogo bakalavriata 1 goda obucheniia kak antropopraktika [Tutoring support of $1^{\text {st }}$ year undergraduate students majoring in pedagogy as anthropological practical work]. In Issledovatel' [Researcher], 1-2 (21-22): 139-142. 
Lee, S.K., Lindsey, N., Kim, K.S. (2017). The Effects of News Consumption via Social Media and News Information Overload on the Perceptions of Journalism. In Computers in Human Behavior, 75: 254263. DOI: 10.1016/j.chb.2017.05.007

McEnnis, S. (2017). Playing on the Same Pitch. In Digital Journalism, 5(5): 549-566. DOI: $10.1080 / 21670811.2016 .1246374$

Miller, S., (2006). Journalism Training in Sri Lanka: Meeting the Needs of Working Journalists. In Changing English, 13(2): 173-178.

Mirkes, M.M., Mukha, N.V. (2010). Obrazovatelnoe sobytie kak tiutorskaia praktika [Educative Event as a Tutoring Practical Session]. In Novye tsennosti obrazovaniia [New Educational Values], 43(1): 91-98.

Muchtar, N., Hanitzsch, T. (2013). Culture clash: International media training and the difficult adoption of Western journalism practices among Indonesian radio journalists. In Journalism Practice, 7(2): 184-198.

Nölleke, D., Grimmer, C.G., Horky, T. (2017). News Sources and Follow-up Communication: Facets of complementarity between sports journalism and social media. In Journalism Practice, 11(4): 509-526. DOI: $10.1080 / 17512786.2015 .1125761$

Pavlik, J.V. (2019). News-Gathering Technologies. In The International Encyclopedia of Journalism Studies. DOI: 10.1002/9781118841570.iejs0235

Stöck1, H. (2017). Multimodality in a Diachronic Light Tracking Changes in Text-Image Relations within the Genre Profile of the MIT Technology Review. In Discourse, Context \& Media, 20: 262-275. DOI: 20. 10.1016/j.dcm.2017.07.001

The State of Social 2018 Report: Your Guide to Latest Social Media Marketing Research (2018). The State of Social 2018, 28.04.2019. Available at: www.buffer.com/resources/state-of-social-2018

Tzelepis, C. et al. (2016). Event-based Media Processing and Analysis: A Survey of the Literature. In Image and Vision Computing, 53: 3-19. DOI: 10.1016/j.imavis.2016.05.005

Ureta, A.L., Fernandez, S.P. (2017). Keeping pace with journalism training in the age of social media and convergence: How worthwhile is it to teach online skills? In Journalism, 19 (6): 877-891. DOI: $10.1177 / 1464884917743174$

Weedon, G., Wilson, B., Yoon, L., Lawson, S. (2018). Where's all the 'good' sports journalism? Sports media research, the sociology of sport, and the question of quality sports reporting. In International Review for the Sociology of Sport, 53(6): 639-667. DOI: 10.1177/1012690216679835 